\title{
Enzymatic Hydrolysis of Gelatin Layers of X-Ray Films and Release of Silver Particles Using Keratinolytic Serine Proteases from Purpureocillium lilacinum LPS \# 876
}

\author{
Ivana A. Cavello, Roque A. Hours, and Sebastián F. Cavalitto* \\ Research and Development Center for Industrial Fermentations, CINDEFI (CONICET - La Plata, UNLP), Calle 47 y 115, (B1900ASH), La \\ Plata, Argentina
}

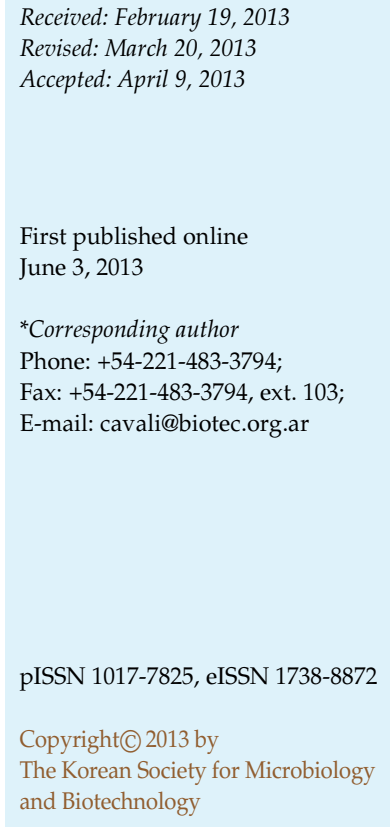

Enzymatic decomposition of gelatin layers on used X-ray films and repeated utilization of the enzyme for potential application in silver recovery were investigated using keratinolytic serine proteases from Purpureocillium lilacinum LPS \# 876. At pH 9.0, the enzymatic reaction was enhanced by the increase of enzyme concentration or by the increase of the temperature up to $60^{\circ} \mathrm{C}$. Under the conditions of $6.9 \mathrm{U} / \mathrm{ml}, 60^{\circ} \mathrm{C}$, and $\mathrm{pH} 9.0$, hydrolysis of the gelatin layers and the resulting release of silver particles were achieved within $6 \mathrm{~min}$. The protective effect of polyols against thermal denaturation was investigated. The presence of glycerol and propylene glycol increased enzyme stability. When the reusability of the enzyme for gelatin hydrolysis was tested, it could be seen that it could be effectively reused for more cycles when glycerol was added, compared with the enzyme without protective agents. The results of these repeated treatments suggested that a continuous process of recycling silver from used X-ray is feasible. Keeping in mind that recycling is (at the present time) needed and imperative, it can be remarked that, in this research, three wastes were successfully used: hair waste in order to produce serine proteases; glycerol in order to enhance enzyme thermal stability; and used Xray films in order to recover silver and PET films.

Keywords: Silver recovery, serine proteases, X-ray films, thermostability.

\section{Introduction}

X-ray film is a poly (ethylene terephthalate) (PET) sheet, coated on both sides by radioactive material, which is sensitive to light. It is used for industrial purposes, and medical and dental services. Around the world, more than 2 billion radiographs are taken each year, including chest X-rays, mammograms, CT scans, etc. [9]. The amount of silver in this kind of films varies between $1.5 \%$ and $2.0 \%$ by weight. According to this, the waste X-ray films (containing black metallic silver spread in gelatin) are a very good source for silver and PET recovery [13]. Several studies have been carried out over a long period of time to recover the silver from wastes radiographic films. Two typical ways to recover silver from used X-ray films are combustion technology and the acid leaching process. Used X-ray films are incinerated at high temperatures and the silver is recovered from ash by smelting and refining processes, whereas in the acid leaching process, they are submerged into a strong acid solution in order to extract the gelatine [8].

Although incineration of the used X-ray films is a conventional method used at the present for the recovery of silver, this method generates an undesirable foul smell, and the PET film cannot be recovered, adding to the environmental pollution caused. Moreover, this is an expensive method to recover silver because of the cost of maintaining the furnace and treating the effluent soot and smoke [15].

Therefore, there is a need to develop cost-effective and environmentally friendly methods to recover both silver and PET from X-ray/photographic waste. Since the emulsion layer on $\mathrm{X}$-ray film contains silver spread in gelatin, it is 
possible to break down this protein layer using proteolytic enzymes with the concomitant release of silver $[13,16]$. The enzymatic hydrolysis of the gelatin layers on the X-ray film enables not only the recovery of silver but also the PET base, which can be recycled. In recent years, just a few works using microbial proteases have been reported as an alternative to the burning and oxidation methods in the silver recovery from X-ray films [6, 12, 13, 15, 16]. Most of the proteases used for silver recovery are of bacterial origin; only Shankar et al. [15] reported the potential use of a fungal alkaline protease from Conidiobolus coronatus for this purpose.

Purpureocillium lilacinum (formerly Paecilomyces lilacinus) LPS \# 876 was found to produce keratinolytic serine proteases when grown in liquid cultures using hair waste as substrate [3]. Hair waste is recognized as a solid waste generated after a hair-saving unhairing process in leather technology, and it is produced in large amounts in Buenos Aires Province, Argentine. At the present time, the unique option for this solid waste is its disposal, which results in an environmental problem and a loss of money for the tanneries because of the cost of it disposal. Biodegradation of hair waste by keratinolytic microorganisms represents an alternative for the bioconversion of keratin waste and generates value-added products, like enzymes that can even been used for the treatment of other industrial wastes such as X-ray film wastes.

In the present work, the decomposition of gelatin layers on X-ray films and the consequent silver removal were investigated using keratinolytic serine proteases produced by P. lilacinum. In addition, several studies were conducted in order to increase the thermostability of the crude enzyme with the aim to enhance the reuse of these enzymes in repeated cycles of gelatin hydrolysis and silver removal from used X-ray films at high temperatures.

\section{Materials and Methods}

\section{Microorganism and Culture Conditions}

P. lilacinum (formerly Paecilomyces lilacinus) LPS \# 876 belonging to the Spegazzini Institute fungal culture collection (La Plata National University, Argentina) was used. It was maintained in potato-dextrose agar slants under mineral oil at $4^{\circ} \mathrm{C}$. Cultures were performed in $500 \mathrm{ml}$ Erlenmeyer flasks with $100 \mathrm{ml}$ of medium containing (per liter) $10 \mathrm{~g}$ hair waste, $496 \mathrm{mg} \mathrm{NaH} \mathrm{PO}_{4}$, $2.486 \mathrm{~g} \mathrm{~K}_{2} \mathrm{HPO}_{4}, 0.16 \mathrm{mg} \mathrm{FeCl} \cdot 6 \mathrm{H}_{2} \mathrm{O}, 0.13 \mathrm{mg} \mathrm{ZnCl}_{2}, 0.10 \mathrm{mg}$ $\mathrm{MgCl}_{2}, 0.011 \mathrm{mg} \mathrm{CaCl}, 2$ g Yeast extract, and 5 g glucose ( $\mathrm{pH}$ 6.0). The culture flasks were autoclaved at $121^{\circ} \mathrm{C}$ for $15 \mathrm{~min}$ for sterilization and then, after cooling, inoculated with $2 \times 10^{7}$ conidia $/ \mathrm{ml}$. The cultures were incubated in an orbital shaker at $200 \mathrm{rpm}$ and $28^{\circ} \mathrm{C}$.
After $111 \mathrm{~h}$ of cultivation, all the contents of each flask were withdrawn and centrifuged at 5,000 $\times g$ and $4^{\circ} \mathrm{C}$ for $20 \mathrm{~min}$ in order to precipitate the fungal biomass. The cell-free supernatant was used as a source of enzyme for silver recovery and thermostability studies.

\section{Determination of Proteolytic Activity}

Protease activity was measured as described by Liggieri et al. [10] using azocasein as substrate, but with some modifications. An aliquot of $0.1 \mathrm{ml}$ of the enzyme preparation, suitably diluted, was mixed with $0.250 \mathrm{ml}$ of Tris- $\mathrm{HCl}$ buffer $(100 \mathrm{mM}, \mathrm{pH} 9.0)$ containing $1 \%(\mathrm{w} / \mathrm{v})$ azocasein, and incubated for $30 \mathrm{~min}$ at $37^{\circ} \mathrm{C}$. The reaction was stopped by the addition of $1.0 \mathrm{ml}$ of trichloroacetic acid $(10 \%(\mathrm{w} / \mathrm{v}))$. After a further $15 \mathrm{~min}$ at room temperature, the mixture was centrifuged at 5,000 $\times g$ for $10 \mathrm{~min}$. A reaction blank was performed with $0.1 \mathrm{ml}$ of heat-inactivated enzyme. One milliliter of $1 \mathrm{M} \mathrm{NaOH}$ was then added to $1 \mathrm{ml}$ of the supernatant and the absorbance measured at $440 \mathrm{~nm}$. One unit of protease activity was defined as an increase of 0.1 unit per minute in the absorbance at $440 \mathrm{~nm}$ under those experimental conditions. Azocasein was synthesized as described by Riffel et al. [14]. Determinations were performed at least in triplicate.

\section{Effect of Temperature on Enzyme Stability of P. lilacinum} Protease

The thermostability of the crude enzyme was examined by incubating it at different temperatures ranging from $37^{\circ} \mathrm{C}$ to $60^{\circ} \mathrm{C}$ for $180 \mathrm{~min}$. Aliquots were withdrawn at desired time intervals, and the remaining protease activity was measured under standard assay conditions. The non-heated crude enzyme was taken as $100 \%$.

The protective effects of propylene glycol $(10 \%(\mathrm{v} / \mathrm{v}))$, glycerol $(10 \%(\mathrm{v} / \mathrm{v}))$, sorbitol $(10 \%(\mathrm{w} / \mathrm{v}))$, and polyethylene glycol 4000 (PEG 4000, 10\% (w/v)) on heat inactivation were also studied. The crude enzyme was incubated at $60^{\circ} \mathrm{C}$ with and without the chemicals mentioned above, and residual protease activity was measured at regular intervals under standard assay conditions. Experiments were performed at least in triplicate and data were expressed as means \pm standard deviations.

The first-order rate constants for denaturation $\left(k_{d}\right)$ of the enzyme at $60^{\circ} \mathrm{C}$ were obtained from Eq. (1) after fitting the residual proteolytic activities with respect to incubation time, using firstorder non-linear regression

$$
\text { At } / A_{o}=e^{-k d t}
$$

where At is the enzyme activity at the time $t$, Ao is the initial enzyme activity, $k_{d}$ is the first-order rate constant for denaturation, and $t$ is the time.

The half-life $\left(t_{1 / 2}\right)$ of the enzyme was obtained from Eq. (2).

$$
t_{(1 / 2)}=\ln (2) / k_{d}
$$

\section{Recovery of Silver from X-Ray Films}

Used X-ray films (cut into $2.5 \times 2.5 \mathrm{~cm}$ pieces) were washed with distilled water, wiped with cotton impregnated with ethanol, 
and dried at $40^{\circ} \mathrm{C}$ for $30 \mathrm{~min}$. After that, $0.1627 \mathrm{~g}$ of X-ray film was incubated with $5 \mathrm{ml}$ of crude enzyme ( $\mathrm{pH} 9.0,6.9 \mathrm{U} / \mathrm{ml})$, such that the film was completely immersed in the solution, at $37^{\circ} \mathrm{C}$ in a water bath under continuous shaking. Aliquots were withdrawn periodically to monitor the progress of the reaction by measuring the change in turbidity of the reaction mixture at $660 \mathrm{~nm}$. The hydrolysis time was defined as the time in which turbidity $\left(\mathrm{OD}_{660}\right)$ attained its maximum value $[6,15]$. Measures at $660 \mathrm{~nm}$ were performed at least in triplicate and data were expressed as means \pm standard deviations.

\section{Effect of Temperature on the Hydrolysis of Gelatin Layers}

In order to study the effect of temperature on the hydrolysis of the gelatin layers, several experiments were carried out as described earlier, at $\mathrm{pH} 9.0$ and temperatures ranging from $28^{\circ} \mathrm{C}$ to $65^{\circ} \mathrm{C}$. X-ray films were added to prewarmed crude enzyme, and the reaction was carried out with continuous orbital shaking. Samples were withdrawn at regular times to measure the change in turbidity of the reaction mixture at $660 \mathrm{~nm}$. The extent of hydrolysis was expressed as the percentage compared with the highest absorbance, which was taken as $100 \%$.

\section{Effect of Enzyme Concentration on the Hydrolysis of Gelatin Layers}

The effect of enzyme concentration on the hydrolysis of gelatin was measured by incubating $0.1627 \mathrm{~g}$ of X-ray film $(2.5 \times 2.5 \mathrm{~cm}$ pieces) with $5 \mathrm{ml}$ of crude enzyme at $60^{\circ} \mathrm{C}$ and $\mathrm{pH} 9.0$ and protease activity ranging from 1.7 to $34.5 \mathrm{U} / \mathrm{ml}$. Samples were withdrawn at regular intervals until the gelatin layer was completely stripped off, and the time required for complete removal was noted. The extent of hydrolysis was expressed as the percentage compared with the highest absorbance, which was taken as $100 \%$.

\section{Reusability of the Crude Enzyme for Gelatin and Silver Removal from Used X-Ray Film}

In order to study the reusability of the crude enzyme (how many times could it be reused) for gelatin hydrolysis and silver removal from the $\mathrm{X}$-ray films, several experiments were performed using $6.9 \mathrm{U} / \mathrm{ml}$ of crude enzyme at $60^{\circ} \mathrm{C}$. These experiments were also conducted using protective agents against thermal inactivation such as glycerol and propylene glycol $(10 \%(\mathrm{v} / \mathrm{v}))$. After complete removal of the gelatin, the enzyme-treated $X$-ray film was removed from the reaction mixture and a new untreated one was added to the same crude enzyme solution and the incubation continued until complete removal of gelatin was observed. This procedure was repeated until gelatin hydrolysis stopped. The time required for complete gelatin removal in each cycle was noted [15].

Weight Loss of Used X-Ray Film During Silver Recovery Process and Recovery of Silver

Weight loss of the X-ray films was analyzed by measuring the weight of used X-ray film before and after complete removal of gelatin layer from $2.5 \times 2.5 \mathrm{~cm}$ of the film. Silver recovery was determined using the gravimetric determination described by Christian [4].

\section{Results and Discussion}

Purpureocillium lilacinum LPS \# 876, a locally isolated fungus, produced extracellular serine proteases with keratinolytic activity when the microorganism was cultured batchwise in a low-cost process using hair waste as substrate [3]. It was demonstrated that the crude enzyme has potential use in detergent industries, because of it compatibility with several commercial laundry detergents and it also showed a good washing performance [3]. In this paper, the crude enzyme $(6.9 \mathrm{U} / \mathrm{ml})$ was assessed for it potential application in the decomposition of gelatin layers and silver recovery from used X-ray films.

\section{Effect of Temperature on Enzyme Stability of P. lilacinum}

\section{Protease}

Studies on the thermostability of the enzyme at temperatures ranging from $37^{\circ} \mathrm{C}$ to $60^{\circ} \mathrm{C}$ revealed that it was very stable at low temperatures up to $40^{\circ} \mathrm{C}$, and for temperatures above $40^{\circ} \mathrm{C}$, heat inactivation displayed typical first-order kinetics (Fig. $1 \mathrm{~A}$ ). At $50^{\circ} \mathrm{C}$, the enzyme had a half-life $\left(t_{1 / 2}\right)$ of $70 \mathrm{~min}$, whereas at $60^{\circ} \mathrm{C}$ the $t_{1 / 2}$ was $12 \mathrm{~min}$. Comparing with others reports, $P$. lilacinum protease seems to be more stable than the alkaline protease of Conidiobolus coronatus NCL 86.8.20 that was completely inactivated at $50^{\circ} \mathrm{C}$ after $1 \mathrm{~h}$ of incubation [2] or more stable than the proteases reported by Nakiboğlu et al. [13] (at $60^{\circ} \mathrm{C}$, these enzymes were rapidly inactivated).

It was observed that there was a noteworthy increase in the protease half-life $\left(t_{1 / 2}\right)$ at $60^{\circ} \mathrm{C}$ when polyols were added. Compared with the control, the $t_{1 / 2}$ was increased around 2.1- and 1.5-fold when glycerol and propylene glycol were added, respectively. PEG 4000 and sorbitol slightly enhanced the enzyme half-life $\left(t_{1 / 2}\right)$ (Fig. 1B).

As can be seen in Table 1, the $k_{d}$ value for crude enzyme was significantly higher without polyols than in the presence of glycerol or of propylene glycol, suggesting a protective effect of these polyols against thermal inactivation, whereas the $k_{d}$ in the presence of sorbitol or PEG 4000 was slightly lower. Another thermal inactivation parameter that is generally used to represent a first-order reaction is the $\mathrm{D}$ value, which is the time needed for a 10 -fold reduction of the initial activity at a given temperature, and it is obtained by plotting activity values on a log scale against the corresponding inactivation times. The higher $\mathrm{D}$ values in the presence of glycerol or propylene glycol represent the 

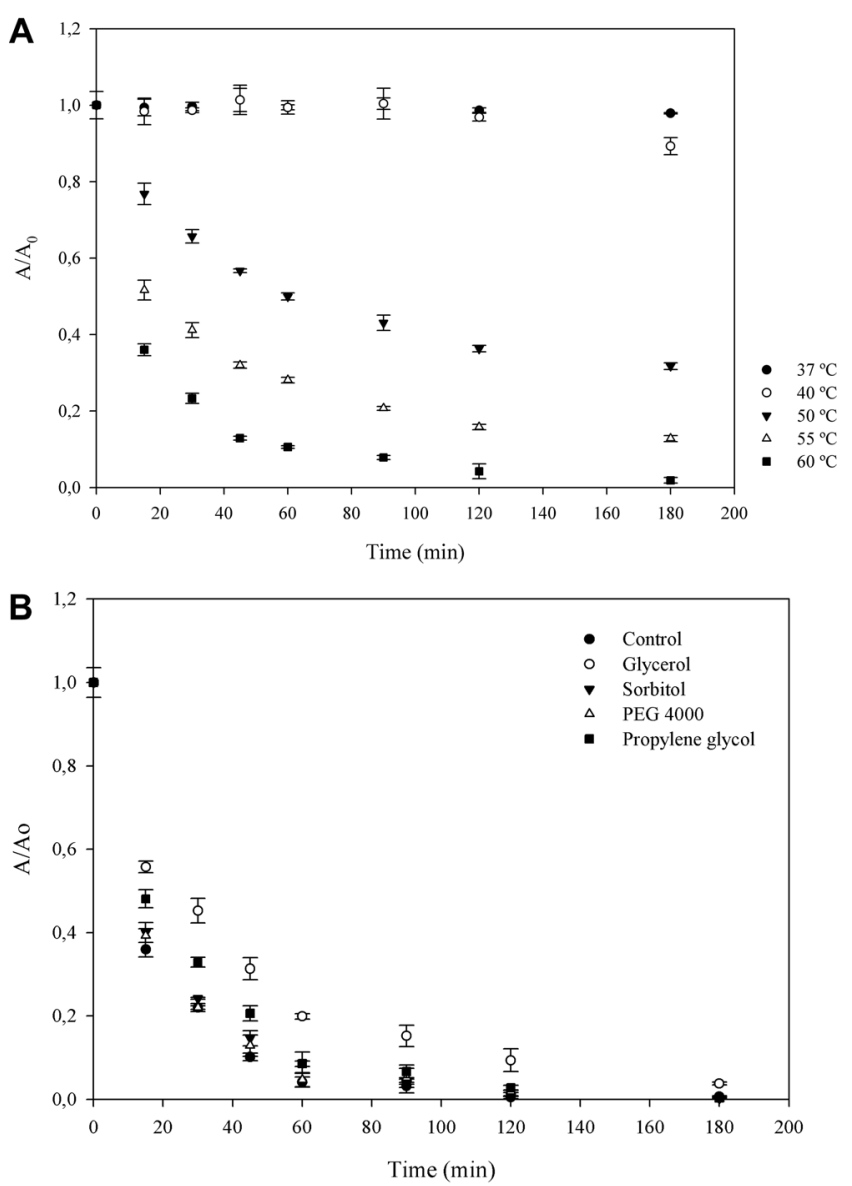

Fig. 1. Temperature and polyols effects on Purpureocillium lilacinum LPS \# 876 protease activity.

(A) Residual activity $\left(\mathrm{A} / \mathrm{A}_{0}\right)$ of $P$. lilacinum protease at different temperatures: $(\bullet) 37^{\circ} \mathrm{C},(\bigcirc) 40^{\circ} \mathrm{C},(\nabla) 50^{\circ} \mathrm{C},(\triangle) 55^{\circ} \mathrm{C}$, and $(\boldsymbol{\nabla}) 60^{\circ} \mathrm{C}$. (B) Residual activity $\left(\mathrm{A} / \mathrm{A}_{0}\right)$ of $P$. lilacinum protease submitted to heating at $60^{\circ} \mathrm{C}$, fitted to first-order model, in the presence or absence of polyols: $(\bullet)$ Control, $(\bigcirc)$ Glycerol, $(\boldsymbol{\nabla})$ Sorbitol, $(\triangle)$ PEG 4000, (匹) Propylene glycol.

enhanced stability of $P$. lilacinum protease. It is well kwon that water plays an important role in influencing the thermostability of enzymes. Sugars or polyols modify the structure of water or strengthen hydrophobic interactions

Table 1. Thermal inactivation parameters of $P$. lilacinum proteases in the presence of various polyols.

\begin{tabular}{lccc}
\hline & $\mathrm{k}_{\mathrm{d}}\left(\mathrm{min}^{-1}\right)$ & $\mathrm{t}_{1 / 2}(\mathrm{~min})$ & $D(\mathrm{~min})$ \\
\hline Control & 0.058 & 12.0 & 39.6 \\
Propylene glycol & 0.039 & 17.7 & 60.0 \\
Glycerol & 0.027 & 25.6 & 85.3 \\
Sorbitol & 0.050 & 13.8 & 46.9 \\
PEG 4000 & 0.054 & 12.8 & 42.5 \\
\hline
\end{tabular}

among nonpolar amino acids, thereby making them resistant to unfolding and thermal denaturation [2]. Ghorbel et al. [7] studied the protective effect of several polyols at $60^{\circ} \mathrm{C}$, finding that BG1 protease has a half-life of 180 and $45 \mathrm{~min}$ in the presence or absence of sorbitol, respectively. Similar studies concerning the protective effects of polyols against thermal inactivation were reported by Cobos and Estrada [5] for a xylanase from Trichoderma reesei QM 9414; by Bhosale et al. [2] for an alkaline protease from Conidiobolus coronatus (NCL 86.8.20); and by Bayoudh et al. [1] for an alkaline protease from Pseudomonas aeruginosa MN1.

With the aim to enhance the reusability of the P. lilacinum enzymes in repeated cycles of gelatin hydrolysis and silver removal from used X-ray film at high temperatures, glycerol and propylene glycol $(10 \%(\mathrm{v} / \mathrm{v}))$ were selected for enhancement of enzyme stability.

Recovery of Silver from X-Ray Films: Effect of Temperature on the Hydrolysis of Gelatin Layers

First, enzymatic decomposition of the gelatin layers was carried out by using crude enzyme $(6.9 \mathrm{U} / \mathrm{ml})$ at $37^{\circ} \mathrm{C}$. Crude enzyme protease decomposed $41.0 \%$ of the gelatin layers after $15 \mathrm{~min}$, and complete breakdown of the gelatin layer was achieved after $33 \mathrm{~min}$ (Fig. 2A). After that, the effect of temperature on the time course of the gelatin hydrolysis was tested (Fig. 2B). Because of the heterogeneous nature of the reaction, a lag phase was observed in the hydrolysis reaction owing to the difficulty of moving the enzyme from the bulk of the solution to the gelatin layer because of mass transfer resistant. During the time course of the reaction, the amount of the enzyme adsorbed to the film increased, resulting in an augmentation of the hydrolysis rate [12]. As can be seen in Fig. 2B, the reaction rate of the gelatin hydrolysis and resulting release of silver particles improved significantly when the temperature was raised, and the maximum rate was observed at $60^{\circ} \mathrm{C}$. The hydrolysis time for complete decomposition at $50^{\circ} \mathrm{C}$ was $20 \mathrm{~min}$, whereas at $60^{\circ} \mathrm{C}$ it was $6 \mathrm{~min}$. With a further raise in temperature to $65^{\circ} \mathrm{C}$, the rate dropped owing to thermal denaturation of the enzyme. Masui et al. [11] reported that at $50^{\circ} \mathrm{C}$, Bacillus sp. B21-2 protease took about $45 \mathrm{~min}$ for the complete hydrolysis, whereas Nakiboğlu et al. [13] reported that Bacillus subtilis ATCC 663 protease took less than $15 \mathrm{~min}$ at $50^{\circ} \mathrm{C}$, but at $60^{\circ} \mathrm{C}$ the enzyme was rapidly inactivated. Complete hydrolysis was achieved within $6 \mathrm{~min}$ at $40^{\circ} \mathrm{C}$ by C. coronatus protease [15]. However, the fungal enzymes of the latter mentioned study [15] showed hydrolytic action only at $40^{\circ} \mathrm{C}$, unlike the protease of this study, which can act over a broad temperature range $\left(37-65^{\circ} \mathrm{C}\right)$. 

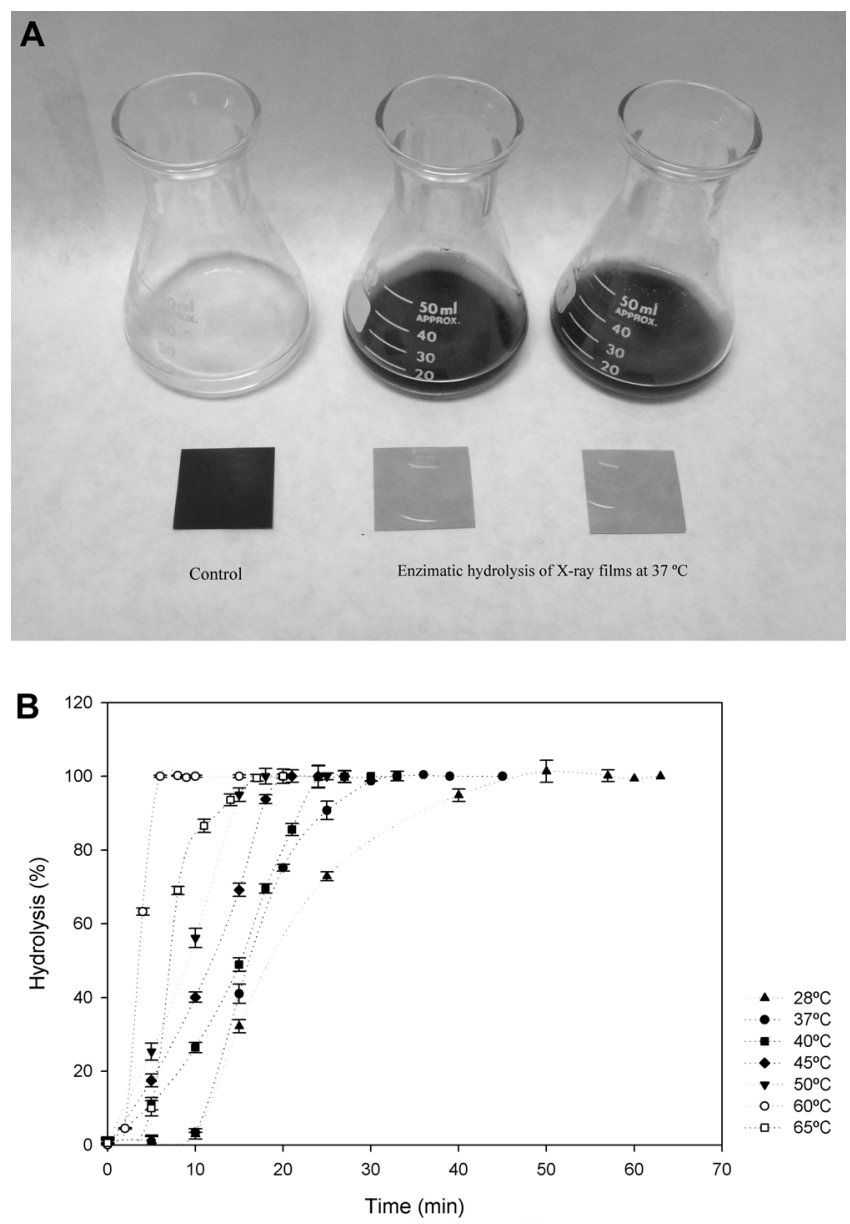

Fig. 2. Enzyme hydrolysis of used X-ray film and gelatin.

(A) Enzymatic hydrolysis of used X-ray films at $37^{\circ} \mathrm{C}$. Control solution remains clear whereas the enzyme solution turns turbid owing to the release of black metallic silver. Clean PET films were obtained after enzyme treatment of X-ray films, whereas the control film remains unchanged. (B) Effect of temperature on time courses of gelatin hydrolysis: ( $) 28^{\circ} \mathrm{C},(\bullet) 37^{\circ} \mathrm{C},(\boldsymbol{\square}) 40^{\circ} \mathrm{C},(\diamond) 45^{\circ} \mathrm{C},(\nabla) 50^{\circ} \mathrm{C}$, $(\bigcirc) 60^{\circ} \mathrm{C}$, and $(\square) 65^{\circ} \mathrm{C}$. Enzyme concentration was $6.9 \mathrm{U} / \mathrm{ml}$.

\section{Effect of Enzyme Concentration on the Hydrolysis of Gelatin Layers}

The effect of enzyme activity on the reaction was studied in the range of 1.7 to $34.5 \mathrm{U} / \mathrm{ml}\left(\mathrm{pH} \mathrm{9.0)}\right.$ at $60^{\circ} \mathrm{C}$ (Fig. 3). Hydrolysis was slow at low protease activity. The time for complete hydrolysis was $27 \mathrm{~min}$ at $1.7 \mathrm{U} / \mathrm{ml}$ and varied from 18 to $5 \mathrm{~min}$ in the activity range from 3.45 to $34.5 \mathrm{U} / \mathrm{ml}$, showing that a saturation of the gelatin layer was achieved where the available surface (not the enzyme) limits the reaction rate. These results seem to be better than those reported by Singh et al. [16] for B. sphaericus protease. This protease took around 24 min to complete hydrolysis at

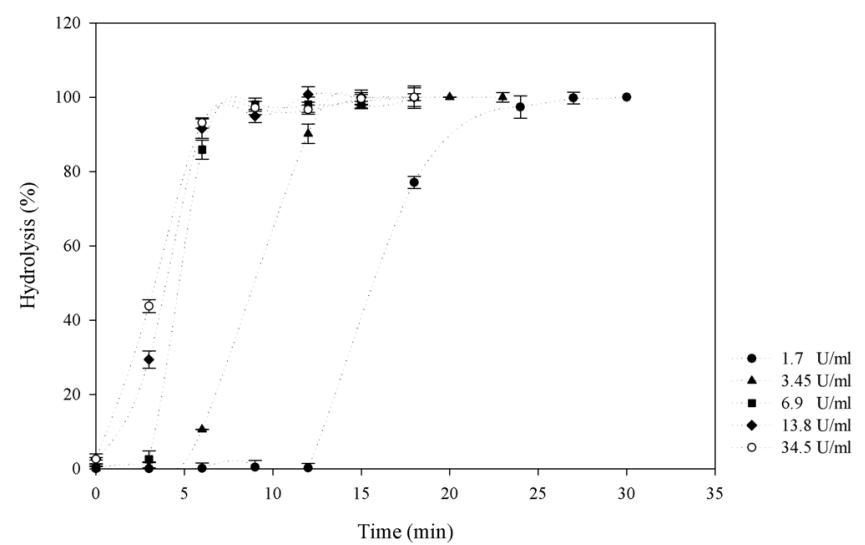

Fig. 3. Effect of enzyme concentration on time courses of gelatin hydrolysis at $60^{\circ} \mathrm{C}$.

(•) $1.7,(\Delta) 3.4,(\square) 6.9,(\diamond) 13.8$, and $(\bigcirc) 34.5 \mathrm{U} / \mathrm{ml}$.

$10 \mathrm{U} / \mathrm{ml}$, and varied from 12 to $8 \mathrm{~min}$ when the activity of protease enzyme varied from 25 to $100 \mathrm{U} / \mathrm{ml}$ (using azocasein as substrate for protease activity determination). Since processing at low cost is attractive from an industrial standpoint, $6.9 \mathrm{U} / \mathrm{ml}$ was found to be most suitable for processing used X-ray films in $6 \mathrm{~min}$.

\section{Reusability of the Crude Enzyme for Gelatin and Silver Removal from Used X-Ray Film}

The ability of the crude enzyme to retain its activity for repeated use makes it suitable for industrial application. It was found that proteases from P. lilacinum could be reused for three cycles without the addition of protective agents and in the presence of propylene glycol; but in the presence of glycerol, $P$. lilacinum protease could be even reused for seven cycles. It can be seen that the decomposition time increased with the cycles (Table 2). After the second cycle of hydrolysis, the enzyme in the presence of polyols took less hydrolysis time than enzyme without them. Masui et al. [11] and Shankar et al. [15] noted that the treatment time increased after every reuse of the enzyme, and the first cycle took $60 \mathrm{~min}$ for complete decomposition and the second one required more than $2 \mathrm{~h}$. It is worth to mention that, although Fujiwara et al. [6] and Singh et al. [16] studied the protective effect of $\mathrm{Ca}^{2+}$ against thermal denaturation, none of them studied the potential reuse of the enzyme nor the potential use of the ion in the reuse cycles. When compared with the proteases reported by Masui et al. [11] and Shankar et al. [15], P. lilacinum protease seems to be more efficient, as it was capable of withstanding reuse to a greater extent, using glycerol as a protective agent against thermal denaturation. 
Table 2. Reuse of P. lilacinum protease for gelatin hydrolysis from used X-ray films.

\begin{tabular}{cccccccccc}
\hline & \multicolumn{7}{c}{ Time required for complete gelatin removal (min) } \\
\cline { 2 - 8 } & Cycle 1 & Cycle 2 & Cycle 3 & Cycle 4 & Cycle 5 & Cycle 6 & Cycle 7 & Cycle 8 \\
\hline Protease & 6 & 15 & 23 & Ir & - & - & - & - \\
Propylene glycol & 6 & 12 & 25 & Ir & - & - & - & - \\
Glycerol & 6 & 9 & 15 & 20 & 25 & 28 & 32 & Ir \\
\hline
\end{tabular}

$\mathrm{Ir}$, incomplete removal after $45 \mathrm{~min}$.

\section{Weight Loss of Used X-Ray Film During Silver Recovery Process and Recovery of Silver}

The treatment of used X-ray films with P. lilacinum protease resulted in silver bound with gelatin being stripped off into the admixture, and a clean PET film was recovered (Fig. 1). The loss in weight after protease treatment was around $4.6 \pm 0.1 \%$ based on the initial weight of X-ray film. The silver content (as $\mathrm{AgCl}$ ) in the hydrolysate was determined by the gravimetric method and corresponded to $0.62 \%$ based on the weight of X-ray film. Silver chloride can be used to make photographic paper, as pottery glazes, in photochromic lenses, in stained glass manufacture, and in bandages and wound healing products [15].

Nowadays, where natural mineral resources are getting depleted ever faster all over the world, reuse and recycling remains the most feasible option to slow down this exhaustion as well as the environmental pollution. This study reported that P. lilacinum LPS \# 876 protease, produced using as substrate another pollutant waste (hair waste), has potential application for recycling silver and PET from used X-ray films in an eco-friendly way. In addition, using glycerol (a biodiesel waste product) enhances the repeated use of a single dose of enzyme for silver recovery from used X-ray films. In this work, three wastes were used, which is an environment friendly way of treating them instead of the usual way of disposal.

\section{Acknowledgments}

This research work was supported by CONICET. S.F.C. is a member of the Research Career of CONICET, and I.A.C. holds a fellowship of CONICET.

\section{References}

1. Bayoudh A, Gharsallah N, Chamkha M, Dhouib A, Ammar S, Nasri M. 2000. Purification and characterization of an alkaline protease from Pseudomonas aeruginosa MN1. J. Ind. Microbiol. Biotechnol. 24: 291-295.
2. Bhosale SH, Rao MB, Deshpande VV, Srinivasan MC. 1995. Thermostability of high-activity alkaline protease from Conidiobolus coronatus (NCL 86.8.20). Enzyme Microb. Technol. 17: 136-139.

3. Cavello IA, Hours R, Cavalitto SF. 2012. Bioprocessing of "Hair Waste" by Paecilomyces lilacinus as a source of a bleachstable, alkaline, and thermostable keratinase with potential application as a laundry detergent additive: characterization and wash performance analysis. Biotechnol. Res. Int. 2012: 112.

4. Christian GD. 1994. Analytical Chemistry, pp. 683-686. 5th Ed. John Wiley and Sons, New York

5. Cobos A, Estrada P. 2003. Effect of polyhydroxylic cosolvents on the thermostability and activity of xylanase from Trichoderma reesei QM 9414. Enzyme Microb. Technol. 33: 810-818.

6. Fujiwara N, Yamamoto K, Masui A. 1991. Utilization of a thermostable alkaline protease from an alkalophilic thermophile for the recovery of silver from used x-ray film. J. Ferment. Bioeng. 72: 306-308.

7. Ghorbel B, Sellami-Kamoun A, Nasri M. 2003. Stability studies of protease from Bacillus cereus BG1. Enzyme Microb. Technol. 32: 513-518.

8. Ishikawa $H$, Ishimi $K$, Sugiura $M$, Sowa A, Fujiwara N. 1993. Kinetic and mechanism of enzymatic hydrolysis of gelatin layers of X-ray film and release of silver particles. $J$. Ferment. Bioeng. 76: 300-305.

9. Khunprasert P, Grisdanurak N, Thaveesri J, Danutra V, Puttitavorn W. 2008. Radiographic film waste management in Thailand and cleaner technology for silver leaching. $J$. Clean. Prod. 16: 28-36.

10. Liggieri C, Arribére MC, Trejo S, Canals F, Avilés F, Priolo N. 2004. Purification and biochemical characterization of asclepain c I from the latex of Asclepias curassavica L. Protein J. 23: 403-411.

11. Masui A, Fujiwara N, Takagi M, Imanaka T. 1999. Feasibility study for decomposition of gelatin layers on $\mathrm{X}$ ray films by thermostable alkaline protease from alkaliphilic Bacillus sp. Biotechnol. Tech. 13: 813-815.

12. Masui A, Yasuda M, Fujiwara N, Ishikawa H. 2004. Enzymatic hydrolysis of gelatin layers on used lith film using thermostable alkaline protease for recovery of silver and PET. Biotechnol. Progress 20: 1267-1269. 
13. Nakiboğlu N, Oscali D, Aşa I. 2000. Silver recovery from waste photographic films by an enzymatic method. Turkish J. Chem. 25: 349-353.

14. Riffel A, Lucas F, Heeb P, Brandelli A. 2003. Characterization of a new keratinolytic bacterium that completely degrades native feather keratin. Arch. Microbiol. 179: 258-265.

15. Shankar S, More SV, Seeta Laxman R. 2010. Recovery of silver from waste $\mathrm{x}$-ray film by alkaline protease from
Conidiobolus coronatus. Kathmandu Univ. J. Sci. Eng. Technol. 6: 60-69.

16. Singh J, Vohra RM, Sahoo DK. 1999. Alkaline protease from a new obligate alkalophilic isolate of Bacillus sphaericus. Biotechnol. Lett. 21: 921-924. 